\title{
Religious Pluralism and the Challenge for Secularism
}

\author{
Arif A. Jamal \\ Associate Professor, National University of Singapore, Faculty of Law \\ lawaaj@nus.edu.sg \\ Jaclyn L. Neo \\ Associate Professor, National University of Singapore, Faculty of Law \\ jaclyn.neo@nus.edu.sg
}

\begin{abstract}
This essay introduces the Special Issue of the Journal. It discusses how changing religious demographics and heightened religious plurality are challenging existing thinking about, and patterns of, state-religion relations and the nature of the 'secular state'. The essay briefly surveys each of the papers in the Special Issue and highlights that one of the key lessons that emerges from the papers is the importance of context. As the contexts evolve, fresh thinking and new arrangements would be needed.
\end{abstract}

\section{Keywords}

religious pluralism - secularism - state-religion relations 
A clearly visible cross must be placed in the entrance area of every service building to serve as a reminder of the historical and cultural influence of Bavaria.

On 1 June 2018, a new law came into effect in the German state of Bavaria. As public offices started hanging crosses in their foyers in compliance with the law, anyone having to deal with Bavarian state officials-whether making a police report, filing their taxes, or walking into an administrative court-would now be greeted by a cross. ${ }^{1}$ In announcing this decree in April, the Bavarian Minister-President, Markus Söder, declared that the move stemmed from a "commitment to Bavarian identity and culture," and that it did not violate the principle of state neutrality as the cross is "not a sign of religion."

The Bavarian law is just one manifestation of the myriad reactions that have emerged across self-avowedly secular regimes worldwide, ostensibly seeking to counter and address rising religious plurality within their borders. The secular state had assumed that religion, specifically Christianity, would take up its proper place in the private sphere, but the (re)emergence of public religion, or what Sajó and others have called "strong religion,"3 has challenged, if not critically eroded, this assumption. Increasingly, immigrants have been bringing their non-Christian religions into legal, political, and social spaces formerly dominated by Christianity, further straining the state-religion compromise and resulting in what some have called a "crisis of identity"4 in many secular states.

Changing religious demography across the world has long challenged the secularizing assumption that underlies much of the relationship of the secular

1 Rebecca Staudenmaier, "Germany: Bavaria's controversial cross rule goes into effect" 2018. DW, 31 May. Retrieved 14 June 2018, http://www.dw.com/en/germany-bavarias-controversial -cross-rule-goes-into-effect/a-44027316.

2 Crosses must be mounted in all state buildings, Bavaria orders. The Local, 25 April 2018. Retrieved 14 June 2018, https://www.thelocal.de/20180425/crosses-to-be-mandatory-in-all -public-offices-in-bavaria.

3 András Sajó, "Preliminaries to a concept of constitutional secularism," 6(3\&4) International Journal of Constitutional Law (2008), 605; cf. Lorenzo Zucca, "The Crisis of the Secular StateA Reply to Professor Sajó," 7(3) I-CON (2009), 494.

4 See e.g. Athika Shubert \& Judith Vonberg, "Crosses go up in public buildings across Bavaria as new law takes effect” 2018. CNN, 1 June. Retrieved 14 June 2018, https://edition.cnn.com/ 2018/05/31/europe/bavaria-germany-crosses-public-buildings-intl/index.html. 
state with established religions. As Talal Asad has noted: "From the point of view of secularism, religion has the option of confining itself to private belief and worship or of engaging in public talk that makes no demands on life ... Either is equally the condition of legitimacy." ${ }^{5}$ Empirically, however, studies show a significant majority of the global population having some religious affiliation. A Pew Research Center report from 2012 observed:

Worldwide, more than eight-in-ten people identify with a religious group. A comprehensive demographic study of more than 230 countries and territories conducted by the Pew Research Center's Forum on Religion \& Public Life estimates that there are 5.8 billion religiously affiliated adults and children around the globe, representing $84 \%$ of the 2010 world population of 6.9 billion. ${ }^{6}$

Pew also noted that "Roughly one-in-six people around the globe (1.1 billion, or $16 \%)$ have no religious affiliation. This makes the unaffiliated the third-largest religious group worldwide, behind Christians and Muslims, and about equal in size to the world's Catholic population."7 In a later report, in 2015, Pew speculated that the unaffiliated are expected to decline as a percentage of the global population, but "are expected to continue to increase as a share of the population in much of Europe and North America." In the US, for example, the unaffiliated are projected to grow from an estimated $16 \%$ of the total population (including children) in 2010 to $26 \%$ in $2050 .{ }^{9}$

In Europe and North America, the secular state has its roots in a compromise between the state and the majority religion, Christianity, largely to address fierce sectarian disputes within that majority religion. But the changing religious demography means that the secular state must address religious plurality not only among different religions, but also between religions and those professing no-religion. As the unaffiliated - the "nones" - increase in number, they may assert stronger claims against religion as part of what they see to be the realization of the promise of the secular state.

5 Talal Asad, Formations of the Secular: Christianity, Islam, Modernity (2003), 199.

6 Pew Research Center, "The Global Religious Landscape" (2012). Retrieved 24 May 2017, http:// www.pewforum.org/2012/12/18/global-religious-landscape-exec/.

7 Ibid.

8 Pew Research Center, "The Future of World Religions: Population Growth Projections, 2010-2050" (2015). Retrieved 24 May 2017, http://www.pewforum.org/2015/04/o2/religious -projections-2010-2050/.

9 Ibid. 
But, secularism and the secular state are not monolithic. At its core, secularism rejects the centrality of religion in government. ${ }^{10}$ The often-claimed division of state from religion in the public and private domains originates in the particular Christian European intellectual history. ${ }^{11}$ But as Silvio Ferrari and others have noted, even in Europe there are variations of the secular state. ${ }^{12}$

The theme of growing religious pluralism and the challenge it poses for secular thought, which has dominated the intellectual landscape at both domestic and international levels, runs through all the articles in this Special Issue. The issue is not novel. In response to the gauntlet thrown down by increasing societal pluralism, scholars like Charles Taylor have proposed modifications to the dominant separationist or non-establishment approach. Taylor argued for a form of state neutrality or "principled distance," a term proposed by Rajeev Bhargava, ${ }^{13}$ to address pluralism. ${ }^{14}$ Taylor's view of secularism is more complex and capacious, as he focuses on the goals or goods to be achieved through secularism, namely, liberty, equality, and fraternity (as derived from the French Revolution).

First, no one must be forced in the domain of religion, or basic belief. This is what is often defined as religious liberty, including of course, the freedom not to believe ... Second, there must be equality between people of different faiths or basic beliefs; no religious outlook or (religious or areligious) Weltanschauung can enjoy a privileged status, let alone be adopted as the official view of the state. Third, all spiritual families must be heard, included in the ongoing process of determining what the society is about (its political identity) and how it is going to realize these goals (the exact regime of rights and privileges). This (stretching the point a little) is what corresponds to "fraternity."15

10 George Jacob Holyoake, English Secularism: A Confession of Belief (1896).

11 See, e.g., John Locke, "A Letter Concerning Toleration," reprinted in J. Horton and S. Mendus (eds.), John Locke: A Letter Concerning Toleration In Focus (1991), 17.

12 See, e.g., Silvio Ferrari, "Models of State-Religion Relations in Western Europe," in A.D. Hertzke (ed.), The Future of Religious Freedom: Global Challenges (2012), 202, 204-205; Lorenzo Zucca, A Secular Europe: Law and Religion in the European Constitutional Landscape (2012); Ahmet T. Kuru, Secularism and State Policies Toward Religion: The United States, France, and Turkey (2009); Jaclyn L. Neo, "Secular Constitutionalism in Singapore: Between Equality and Hierarchy," 5(3) Oxford Journal of Law and Religion (2016), 431.

13 Rajeev Bhargava, "The Distinctiveness of Indian Secularism," in T.N. Srinivasan (ed.), The Future of Secularism (2006).

14 Charles Taylor, "The Meaning of Secularism," 12(3) The Hedgehog Review (2010), 23.

15 Ibid. 
Notably, Taylor does not merely emphasize rights and liberty, but also the need for the procedural inclusion of all groups. Furthermore, he adds a fourth goalthe need to maintain relations of harmony and comity between supporters of different religions and Weltanschaungen. ${ }^{16}$ This focus on relations between different groups in society is important because it departs from a strictly rights-and-equality approach to secularism. Therefore, secularism is viewed not merely from an institutional separation perspective, which may be exclusionary of religious voices, or based upon the need to protect individual rights, which is often the emphasis in liberal secular theory, but also as a policy or approach necessitating positive inclusion and comity.

The need for inclusivity is also emphasized in Lorenzo Zucca's work. He proposed a new model of "inclusive secularism" focused on "the art of devising institutions for plural societies to maximize religious diversity, at the same time preserving a unitary legal-political framework."17 Zucca seeks to mitigate some of the exclusionary tendencies of the secular state: the "secular state should not silence religious voices" but instead "allow for their participation in the public sphere."18 We call this approach mitigating because it still retains the structure and substance of the secular state, which has the ultimate authority to set conditions for participation for all. Zucca argues that ultimately, "the final product of deliberation — secular law-can only employ a language that everyone can understand without the need to appeal to transcendentalmetaphysical considerations that are not shared by all."19 Inclusive secularism retains the priority of secular law and the secular framework of the state, a position that may be the most tenable one in Europe because of its given history and the present political climate. Any attempts to universalize this proposed model, however, must be approached with caution when dealing with countries outside Europe, or even outside Western Europe.

Taylor, Zucca and others remind us that we must be alive to the influence of context and the need to carefully consider all relevant societal factors: geographical, demographic, economic and political. The papers in this Special Issue address primarily European and Western contexts, but they emerged from a conference on regulating religion that we organized with another colleague in December 2015 at the Faculty of Law of the National University of Singapore ${ }^{20}$ a forum which also included papers discussing other jurisdictions.

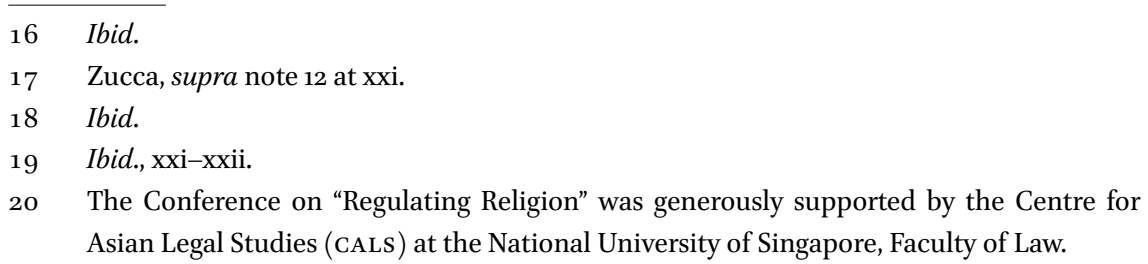


The papers on Asia are to be published in an edited volume entitled, Regulating Religion in Asia: Norms, Modes, and Challenges.$^{21}$ In that collection, we examine the range of jurisdictional practices in the Asian region, using the conceptual tool of regulation.

The essays in this Special Issue complement and extend that work in three ways. First, they go beyond Asia. Second, they are grounded in wider theoretical concerns or arise from certain types of discourse, such as constitutional or international law. Third, and perhaps most significantly, they address the specific challenges in their particular national and regional contexts. These include, to reiterate, the profound issue of how liberal democracies ought to deal with heightened religious pluralism, as well as how to best respond to what has emerged as now contested understanding of the secular state. In addition, three articles (Ferrari, Faraguna, and Calo) examine the importance and meaning of religious symbols, which are becoming poignant flashpoints, especially in Europe.

This Special Issue (and our forthcoming book) highlight the fact that, simply put, context matters. What may appear urgent and controversial in one context may be regarded as banal in another, and what is unfamiliar, odd, and potentially threatening in some places may be commonplace in others. Unsurprisingly, the Singapore conference demonstrated that the situation in Asia and Europe generated different concerns and issues derived from a range of historical, demographic, and social reasons. We are thus reminded that we are, indeed, dealing with secularism and religion in a multicultural age. ${ }^{22}$ Whatever understandings we may have had so far confront the cold reality that, as Asad put it, "if anything is agreed upon, it is that a straightforward narrative of progress from the religious to the secular is no longer acceptable." ${ }^{23}$ We are at a moment when the old models are losing their grip and new arrangements are urgently needed.

It is therefore apt that this Special Issue opens with Silvio Ferrari's article examining the variety of secular approaches in Europe and how each approach could be employed to deal with religious diversification. As he puts it, the "universal dream of Europe had a name: the secular state." Ferrari's article sets the tone for the Issue, as it highlights a key problem the secular state, at least in the West, is encountering What is religious plurality beyond Christian sectarianism? For him, the European project is very much tied to the construction of the

21 Jaclyn L. Neo, Arif A. Jamal, and Daniel P.S. Goh (eds.), Regulating Religion in Asia: Norms, Modes and Challenges (Cambridge University Press) (forthcoming).

22

This is also the title of a chapter in an edited volume: Geoffrey Brahm Levey, "Secularism and religion in a multicultural age," in G.B. Levey and T. Mahmood (eds.), Secularism, Religion and Multicultural Citizenship (2009), 1-25. 
secular state, as universally the "best legal system to regulate relations between states and religions, not only in Europe but everywhere else in the world." He defines this as a "legal system characterized by three features that are at the foundation of the legal definition of the secular state in the West," namely the equal footing of civil and political rights independent of religion; the right to legislate upon important events of human life-birth, marriage, death, and so on-in a purely secular way; and the exclusion of direct references to religious rules in state law.

As the recent Bavarian law we opened with suggests, one way to face up to religious diversification is to invoke the dominant culture, to strengthen and reify it, to endeavour to defend it against new minority cultures that are deemed foreign and threatening. This contrasts with another approach that is often associated with French laïcité which seeks to aggressively remove religion from the public square. ${ }^{24}$ Ferrari describes the three European variations (French, Italian, and British), and identifies distinctions and flaws in these current approaches to religious diversity. Ferrari ties the possible success of these approaches to broader geopolitical developments, trends that he suggests reflect the decline of Europe. The decline is demographic, political, and economic, and Ferrari's argument is that this weakens Europe as an intellectual and ideological leader in the world. The decline also weakens the dominance of the idea of a secular state, but more importantly, results in what Ferrari calls a "lack of confidence," such that there is "continual oscillation between the impulse to confine religion more strictly to the private sphere, excluding it from the process of building the national identity, and the desire to strengthen national identity through the revitalization (and therefore the re-publicization) of the majority religion only." Thus, one can understand initiatives that appear hostile to minority religions - like the Bavarian law on crosses (as well as other laws in Europe banning the burqa (the face veil), and the burkini) — as coming from a position of weakness, real or perceived, rather than one of strength.

Following Ferrari's reflections, Pietro Faraguna contextualizes the construction and reconstruction of the "secular" state by analyzing the evolution of Italian state-church relations. Italy is a fascinating country for the study of state-church relations, not least because it houses within its territory the Vatican City, which is an ecclesiastical or sacerdotal-monarchical state in its own right. Consequently, as Faraguna points out, the Italian state had always had to contend with strong religion first in the form of the state religion, then as a co-equal sovereign. The relationship between Italy and the Roman Catholic Church has always been mediated by a formal institutionalized structure. Faraguna's article highlights one aspect of the evolution of the secular state 
in Europe: the need for the state, in constructing itself, to sometimes negotiate with a culturally historic and powerful church. In contrast, state-religion relations in other parts of the world evolved in ways that did not necessarily involve a hierarchical religious institution, such as the Catholic Church. ${ }^{25}$ By comparison, "Islam knows no 'church' in the sense of a corporate body whose leadership is clearly defined, hierarchical, and distinct from the state."26 Muslim scholars may speak out against a ruler, but it is "virtually impossible" to have an institutional confrontation between a Muslim "church" and a Muslim state, at least within the Sunni tradition. ${ }^{27}$

Faraguna's detailed analysis of three case studies - the teaching of religion in state schools, the display of the crucifix in the classroom, and the funding of organized religion - brings into sharp focus the religious preferentialism that continues to characterize secularism in Italy. State practice there continues to grant a differentiated and higher constitutional status to the Catholic Church, whereby it enjoys distinctly greater privileges than other religions. Faraguna points out that the adequacy of the existing constitutional arrangement, where the secular state shows preference for the Catholic Church, will be tested as demographic changes emerge within Italian society-in the form of growing numbers of the "nones" and those who adhere to religions that are not historically part of the dominant religious traditions of the country. Consistent with the point we emphasized above, profound changes in the religious makeup of society will lead to greater pressures on the existing constitutional settlement in Italy - an uneasy admixture of the secular and a privileged religion.

Both Helge Arsheim's and Jeroen Temperman's articles also focus on how a state grapples with religion concretely and directly, and stress the limitations of the common secularist claim of neutrality. The two articles address the intersection between law and religion in the realm of international law. Arsheim's critical examination of how international human rights law has engaged religion over time provides an instructive insight into its secular underpinnings. As he aptly observes, "[d]erived from the presumed secularism of the Atlantic revolutions, the provisions of the UDHR and ensuing instruments have cordoned off religion to the private domain, with only limited manifestations allowed in the public sphere." He goes on: "The suspicion toward religion as a source of anything more than the private beliefs of individual citizens builds on

25 See, e.g., the account of state-religion relations and religious freedom from the Christian perspective, which demonstrates the critical role of the church in Rex Ahdar and Ian Leigh, Religious Freedom in the Liberal State ( $2^{\text {nd }}$ edn, 2013), ch 2, 23.

26 L. Carl Brown, Religion and State: The Muslim Approach to Politics (2000), 31.

27 Ibid. 
a long-standing civilizational ideal that considers the singularity and unity of a secular legal system as the only acceptable solution for social organization." This approach has tended to dismiss the role of religion in the public sphere, and views "the coexistence of parallel legal orders, or legal pluralism ... as an indicator of incomplete territorial control, and social and political backwardness." Arsheim tracks the shift in the engagement of international human rights law with religion by examining the work of the UN Committee on the Elimination of Discrimination Against Women, the UN Committee on the Rights of the Child, the Human Rights Committee (dealing with the International Covenant on Civil and Political Rights), and the Committee on the Elimination of Racial Discrimination. This engagement represents a basic reworking of the relationship between religion and international human rights law, but also, more fundamentally, to the sense that, perhaps in somewhat mysterious and seldom acknowledged ways, religion provides law with its spirit. Arsheim's analysis of the various organs of international human rights law demonstrates that the story is neither simple nor uniform, as different bodies adopt different points of view. He notes that one significant general challenge arises with respect to how religion sits in relation to other bodies of law. Although there are divergences between these committees, a common theme appears to be the recognition of the need to engage with religious and customary legal systems, and (except with respect to the Human Rights Committee) to pay attention to the social influence of religion in the implementation of human rights provisions. Within some committees, there is a growing reorientation towards legal pluralism to protect a variety of human rights. Arsheim concludes that, given the different viewpoints expressed in the work of these bodies, they should be encouraged to develop a common outlook and work towards a joint official Comment on the place of legal pluralism, and the role of religious concepts therein, in international human rights law. Arsheim's article stresses the persistent influence of religion in society, and the need for law to engage with religion, especially where it seeks to bring about social change.

Temperman's article continues in the same vein, explaining how international law engages with religion, although his focus is on religious groups. His article investigates an important but under-examined provision in the United Nation's International Covenant on Civil and Political Rights (ICCPR), viz, Article 20(2), which stipulates that "[a]ny advocacy of national, racial or religious hatred that constitutes incitement to discrimination, hostility or violence shall be prohibited by law." Temperman asks whether Article 2o(2) contains the "right to be protected against incitement," and if so, what this right consists of. After reviewing different potential understandings of the Article - as a prohibition, as a right of others, as a right invoked by incitement 
victims-Temperman concludes that in Rabbae, A.B.S. and N.A. v. The Netherlands ["Rabbae"], ${ }^{28}$ the Human Rights Committee made clear that Article $20(2)$ is a normal human rights provision after all, and a justiciable right. The decision concerns a complaint brought against the Netherlands for failing to appropriately apply its domestic anti-incitement legislation, which is supposed to give effect to ICCPR standards on incitement. The complainants were Dutch citizens of Moroccan descent who claimed to have personally experienced the negative consequences of anti-Muslim statements made by the infamous Dutch far right politician, Geert Wilders. Wilders had been charged under Dutch law with inciting hatred and discrimination against Muslims, but was acquitted. The complainants lost their case against the Netherlands, but Temperman argues that the significance of the decision lies in the fact that the Committee entertained the complaint in the first place and addressed the allegations on their merits. This, he contends, gives real "bite" to Article 20(2), as it can now be read not merely as a prohibition or state obligation, but also a justiciable right. According to Temperman, this brings the jurisprudence of the Human Rights Committee in line with previous jurisprudence to the same effect by the UN Committee on the Elimination of Racial Discrimination.

Temperman's article, like Arsheim's, illuminates how international law must tussle with the persistent influence of religion. Whereas the international human rights committees examined in Arsheim's article were concerned with the relationship between religion and human rights, at times cast in terms of legal pluralism, Temperman explains how a certain provision of international law that encompasses religion, or the protection of religion-Article 20(2) is being shaped and given it its normative force. His article also highlights, albeit tangentially, how religious groups resort to international law in advancing their causes. Rabbae was a case against the state brought by a group of Muslims who were alleged victims of Wilders. Temperman emphasizes that Rabbae's significance lies in its lesson to religious individuals and groups that they do have standing before the Human Rights Committee under Article 2o(2). The exact scope of this right will have to be determined in future cases, but at the very least, the new jurisprudence, with its justiciable right, opens the door for religious communities to vindicate their faith and underscores the potency of the religious factor in international human rights law.

This Special Issue ends, provocatively and by design, with Zachary Calo's article. He argues that the "secular" is not an abstract formulation but a form of social and moral order that finds its expression in and through law. This 
is an important observation because a country's conception of the secular determines how the state it will interact or regulate religion. Calo's observation that the relationship between law and the social-moral secular order is not unidirectional, but rather the two exist in a dialectical relationship, is a valuable insight into the pluralism of concepts (in addition to contexts). As he says:

But while there certainly are ways in which the current legal situation involves a "clash of universalisms," such an interpretive paradigm does not account for the full complexity of the situation. ${ }^{29}$ Law and religion jurisprudence has not unfolded in simple binary terms, and not only because the lines of division between secular and religious, public and private, are fluid.

Calo suggests neither law nor the secular can be understood without considering the ways in which they inform each other. The process is context-driven, and therefore the expression of these concepts will be different in the US and Europe, notwithstanding their shared post-Christian identities. Calo maintains that we are now witnessing a "secular order increasingly stripped of thick meaning and normativity," resulting in an "exhausted moral state." At this crucial stage, there is "new space for religious freedom and authentic religious pluralism." Thus, for Calo, "We are in medias res. ... [E]ven as the legal situation projects a certain stability, undercurrents of change continue to affect the structural relationship between law and religion."

This liminal state arises not only because of the changes in our understanding of secularism or the secular state, but also because of the changing meaning of religion. Defining religion has always been a difficult task. ${ }^{30}$ The multiplicity of proffered definitions, the challenge of grappling with different religious forms, practices, and beliefs, and the controversies over "new" religions bedevil any neat definitions. Our definitions, therefore, will always be imperfect. This is further complicated by the internal heterogeneity of particular religions. ${ }^{31}$ For instance, to talk of "Christians" one must to take into account different

29 Abdulaziz Sachedina, "The Clash of Universalisms: Religious and Secular in Human Rights," 9(3) The Hedgehog Review (2007), 49-62.

30 Arif A. Jamal, "The impact of definitional issues on the right of freedom of religion and belief" in S. Ferrari (ed.), Routledge Handbook of Law \& Religion (2015), 91, 93.

31 For a discussion on how internal heterogeneity affects definitional questions, see Jaclyn L. Neo, "Definitional imbroglios: A critique of the definition of religion and essential practice tests in religious freedom adjudication," 1 International Journal of Constitutional Law (2018). 
Christian confessions, denominations and churches, which cover a spectrum of distinctive Christian outlooks, practices, and beliefs. As a result, in many situations a particular set of religious commitments may attract the adherence of only a minority within that designated faith community. More importantly, as the secular state tries to cope with religious plurality, it seems to be embarking upon a process of desacralizing religion. By referring to the cross as a "historical and cultural influence of Bavaria," the state is changing the meaning of the cross and hollowing out its religious character. ${ }^{32}$ This raises further challenges. Not only could such a civil religion potentially play an exclusionary function by rejecting persons who do not share the underlying religious tradition or outlook, it also undermines the distinctiveness of religion as a category deserving protection. All this is further complicated as we move not just between the religious and secular, but also the "post-secular," and thus we must confront what legal protections, such as the right of freedom of religion, actually mean in these conditions. ${ }^{33}$

We hope that the articles in this Special Issue will stimulate further serious thinking about religious pluralism, secularism and the state. Finally, we would be remiss if we did not offer our appreciation to the editors of the Journal of Law, Religion and State, with whom it has been our pleasure to work. This was a new venture for both parties, but it benefitted from our joint commitment to share the fruits of thoughtful scholarship.

\section{Acknowledgement}

The authors would like to thank Daryl Yang (NUs Law/Yale Nus Double Degree Program) for editorial assistance, and to acknowledge the funding support of the Centre for Asian Legal Studies (CALS) at the National University of Singapore, Faculty of Law.

32 The Bavarian situation discussed at the opening of this foreword is perhaps the most recent manifestation of this issue, but the well-known European Court of Human Rights case concerning the display of the crucifix in public schools in Italy (Case of Lautsi and others v. Italy (Application no. 30814/o6), 18 March 2011) and the Eweida case concerning an employee's right to wear a religious necklace outside her clothes while working (Eweida v. United Kingdom [2013] ECHR 37), are additional examples of the same point in question.

33 For a discussion, see Arif A. Jamal, "Considering freedom of religion in a post-secular context: hapless or hopeful?", 6(3) Oxford Journal of Law and Religion (2017), 433-45o. https:// doi.org/10.1093/ojlr/rwx046. See also Michael J. Sandel, "Religious Liberty—Freedom of Conscience or Freedom of Choice?", Utah L. Rev. (1989), 597. 